\title{
The effect of nitrogen fertilizer on hybrid maize yields under the shade of coconut trees
}

\author{
Sution*, Muhammad Hatta, L.M. Gufroni Arsjad, and Rustan Marssinai \\ Assessment Institute for Agricultural Technology of West Kalimantan, J1. Budi Utomo No. 45 \\ Pontianak 78241 West Kalimantan, Indonesia.
}

\begin{abstract}
The need for maize in West Kalimantan is around 320,000 tonnes per year, most of which is still imported from outside the region. Cultivating the maize under the shade of coconut trees is an alternative to meet the needs of maize in West Kalimantan and hence improvement on the cultivation of maize under the shade of coconut trees should be taken seriously. This study aims to determine the effect of nitrogen $(\mathrm{N})$ fertilizer on the growth and yield of hybrid maize under the shade of coconut trees. The research method used a factorial randomized block design consisting of 2 factors. The first factor is maize variety (Nasa 29, Bima 19, Bima 20, JH 21 and Pioneer 35) and the second factor is nitrogen fertilization $\left(64 \mathrm{~kg} \mathrm{ha}^{-1}, 86.5 \mathrm{~kg} \mathrm{ha}^{-1}, 109 \mathrm{~kg} \mathrm{ha}^{-1}\right.$, and $131.5 \mathrm{~kg} \mathrm{ha}^{-}$) of $\mathrm{N}$, hence 20 treatment combinations are obtained and repeated 3 times. The results showed that the Nasa 29 variety with $\mathrm{N}$ fertilizer of $131.5 \mathrm{~kg} \mathrm{ha}^{-1}$ produced the highest maize grains yield of $4.8 \mathrm{t} \mathrm{ha}^{-}$ ${ }^{1}$. Therefore the using of Nasa 29 variety with the $131.5 \mathrm{~kg} \mathrm{ha}^{-1}$ of $\mathrm{N}$ fertilizer is recommended for intercropping system under the shade of coconut trees.
\end{abstract}

\section{Introduction}

The demand for corn in Indonesia continues to increase every year, especially for food, animal feed and industrial raw materials. In 2018, the Indonesian corn production projected to 26.5 million tons was increased in 2019 to 27.8 million tons of dry grains. The efforts to meet the corn production objective can be done by optimizing plantation land, such as coconut, oil palm and rubber plantations. This three types of plantation crops covered an area of 19.5 million hectares, and 3.2 million hectares that have the potential to be planted with corn in the immature plantations (TBM), non-productive plants (TTM) and damaged or less productive plants [1].

In West Kalimantan, there is open space between coconut plants that can be planted with food crops such as corn. About $80 \%$ of the land between coconut plants has the potential for intercrop with corn [2]. Corn production in West Kalimantan in 2020 is 103,742 tons and the productivity is $3.7 \mathrm{t} / \mathrm{ha}$. The need for corn in West Kalimantan is around 320,000 tons per year, most of them is still imported from outside the region [3]. In an effort to meet the demand for corn that can be realized by utilizing of coconut plantation land as an intercrop plant. The results from some research showed that corn grown as intercrops among rubber plants can increase corn production and profitable with an $\mathrm{R} / \mathrm{C}$ of 1.62 [4].

* Corresponding author: sution@pertanian.go.id 
The growth and production of maize is largely determined by the climate, especially temperature, rainfall, the sunlight intensity and the nutrients absorption from the soil [5]. Nitrogen elements will absorbed by plants during the growth period until seed maturation, therefore this plant require continuous availability of nitrogen at all stages of growth until seed formation [6]. One of the macro nutrients required by corn plants during their life cycle is nitrogen element $[7,8]$.

The functions of nitrogen in plants are as a synthetic material for chlorophyll, protein, and amino acids [9]. Appropriate fertilizer application during maize plant growth can increase the maize yield. The nature of nitrogen fertilizers is generally mobile, so to reduce nitrogen loss due to leaching and evaporation, the nitrogen is given gradually. Lack or inappropriate application of nitrogen fertilizer provide very detrimental effect to corn plants. In general, nitrogen fertilizers can increase corn production, which is nitrogen required by corn plants throughout their growth. Therefore, there is a requirement for an in-depth study about the effect of shading and level of nitrogen fertilization on the growth and yield of maize as an intercrop among coconut plants. The purpose of this study is to determine the effect of nitrogen fertilizer application on the growth and yield of several hybrid maize varieties under coconut trees.

\section{Materials and methods}

This research was carried out in the field experimental station of the Agricultural Technology Research and Assessment Installation (ATRAI) in Sungai Kakap, West Kalimantan, from February to June 2019. The materials used includes several varieties of corn seeds, agricultural production input like fertilizers and other auxiliary materials, as well as stationery and recording sheet for the field work.

This study used a factorial randomized block design (RCBD) that consisted of 2 factors, the first factor is variety and the second factor is the level of nitrogen fertilizer. The treatments of this experiment were following these arrangement:

Factor I. Varieties consisting of 5 varieties :

$$
\begin{aligned}
\mathrm{V} 1 & =\text { Nasa } 29 \\
\mathrm{~V} 2 & =\text { Bima } 19 \\
\mathrm{~V} 3 & =\text { Bima } 20 \\
\mathrm{~V} 4 & =\mathrm{JH} 21 \\
\mathrm{~V} 5 & =\text { Pionner } 35
\end{aligned}
$$

Factor II. Level of Nitrogen (N) fertilizer which consists of 4 levels, include :

$$
\begin{aligned}
\mathrm{N} 1 & =64 \mathrm{~kg} \mathrm{ha}^{-1} \text { of } \mathrm{N} \text { fertilizer } \\
\mathrm{N} 2 & =86.5 \mathrm{~kg} \mathrm{ha}^{-1} \text { of } \mathrm{N} \text { fertilizer } \\
\mathrm{N} 3 & =109 \mathrm{~kg} \mathrm{ha}^{-1} \text { of } \mathrm{N} \text { fertilizer } \\
\mathrm{N} 4 & =131.5 \mathrm{~kg} \mathrm{ha}^{-1} \text { of } \mathrm{N} \text { fertilizer }
\end{aligned}
$$

From those two factors, there were 20 treatment combinations with 3 replications to produce 60 treatment plots. The treatment combinations are presented in Table 1.

The data from the experimental results of the 2 treatment factors were analyzed using the $\mathrm{F}$ test and continued with the LSD at the level of 5\% [10]. The variables observed were (1) plant height $(\mathrm{cm}),(2)$ cob height $(\mathrm{cm}),(3)$ plant height ratio with cob height, (4) male flower age (days), (5) female flower age (days), (6) delay day (days), (7) ear length $(\mathrm{cm}),(8)$ ear circumference $(\mathrm{cm}),(9)$ number of seeds per row (seeds), (10) number of seeds per ear circumference (seeds), (11) number of seeds per cob (seeds), (12) weight of 1000 grains (g) and corn productivity per hectare $\left(\mathrm{t} \mathrm{ha}^{-1}\right)$. 
The dose of fertilizing corn using agricultural lime $500 \mathrm{~kg}$ ha-1, manure $2 \mathrm{t}$ ha-1, NPK 16-16-16 $400 \mathrm{~kg}$ ha-1 then urea fertilizer as treatment dose $\mathrm{N} 64 \mathrm{~kg}$ ha-1 without urea fertilizer, dose $\mathrm{N} 86,5 \mathrm{~kg}$ ha-1 added urea $50 \mathrm{~kg}$ ha-1, dose of $\mathrm{N} 109 \mathrm{~kg}$ ha-1 added urea 100 $\mathrm{kg}$ ha-1 and dose of $\mathrm{N} 131.5 \mathrm{~kg}$ ha-1 added urea $150 \mathrm{~kg}$ ha- 1 . Corn that planting between coconut plants was carried out at a distance of 1.5 meters from the coconut tree, while the spacing of corn of $70 \mathrm{~cm} \times 20 \mathrm{~cm}$ and coconut planting distance of $8 \mathrm{~m} \times 8 \mathrm{~m}$. In addition to $\mathrm{N}$ fertilizer as a treatment, maize plants were also fertilized with P2O5 and K2O fertilizers at $87 \mathrm{~kg} \mathrm{ha}^{-1}$ and $64 \mathrm{~kg} \mathrm{ha}^{-1}$, respectively, and fertilized with $2 \mathrm{tha}^{-1}$ of chicken manure.

Table 1. Combination of varieties and level of $\mathrm{N}$ treatment

\begin{tabular}{|c|c|c|c|c|}
\hline \multirow{2}{*}{$\begin{array}{c}\text { Factor Treatment I } \\
\text { (Varieteis) }\end{array}$} & \multicolumn{4}{|c|}{ Factor Treatment II (Fertilizer Nitrogen) } \\
\cline { 2 - 5 } & $\begin{array}{c}\mathbf{6 4} \mathbf{~ k g ~ h a}^{-\mathbf{1}} \\
\text { N fertilizer } \\
\text { (N1) }\end{array}$ & $\begin{array}{c}\mathbf{8 6 , 5} \mathbf{~ k g ~ h a}^{-\mathbf{1}} \\
\text { N fertilizer } \\
\text { (N2) }\end{array}$ & $\begin{array}{c}\mathbf{1 0 9} \mathbf{~ k g ~ h a}^{-\mathbf{1}} \\
\mathbf{N} \text { fertilizer } \\
\text { (N3) }\end{array}$ & $\begin{array}{c}\mathbf{1 3 1 , 5} \mathbf{~ k g ~ h a}^{\mathbf{- 1}} \mathbf{~ N} \\
\text { fertilizer } \\
\text { (N4) }\end{array}$ \\
\hline Nasa 29(V1) & V1 P1 & V1 N2 & V1 N3 & V1 N4 \\
\hline Bima 19 (V2) & V2 N1 & V2 N2 & V2 N3 & V2 N4 \\
\hline Bima 20(V3) & V3 N1 & V3 N2 & V3 N3 & V3 N4 \\
\hline JH 21 (V4) & V4 N1 & V4 N2 & V4 N3 & V4 N4 \\
\hline Pionner 35 (V5) & V5 N1 & V5 N2 & V5 N3 & V5 N4 \\
\hline
\end{tabular}

\section{Result and discussions}

The results of statistical analysis in Table 2 shows there was no interaction of corn plant height between the hybrid corn varieties and nitrogen fertilizer level treatment during the plant growth phase. There was no difference on the maize plant height at the age of 30 days after planting (dap). At the age of 60 days after planting (dap), it showed that the Pionner 35 hybrid maize variety had a plant height of $216.56 \mathrm{~cm}$, which is significantly different with other varieties. While the nitrogen fertilizer level treatment had the same plant height. At the age of 90 dap showed the same growth pattern as the age of 60 dap, the Pionner 35 corn variety at $193.54 \mathrm{~cm}$ was the highest plant height compared to other varieties. While the nitrogen fertilizer level treatment provides no difference between treatments.

Table 2. Effect of treatment of several hybrid maize varieties with nitrogen fertilizer level on maize under coconut stands on plant height observations at various plant ages.

\begin{tabular}{|c|c|c|c|}
\hline \multirow{2}{*}{ Treatment } & \multicolumn{3}{|c|}{ Plant Height (cm), at the age of-(dap) } \\
\cline { 2 - 4 } & $\mathbf{3 0}$ dap & $\mathbf{6 0}$ dap & $\mathbf{9 0}$ dap \\
\hline Varieties & & & \\
\hline Nasa 29 & $71.25 \mathrm{a}$ & $198.40 \mathrm{~b}$ & $180.42 \mathrm{~b}$ \\
\hline Bima 19 & $76.04 \mathrm{a}$ & $194.58 \mathrm{bc}$ & $173.23 \mathrm{c}$ \\
\hline Bima 20 & $74.17 \mathrm{a}$ & $195.52 \mathrm{~b}$ & $166.67 \mathrm{~d}$ \\
\hline JH 21 & $75.94 \mathrm{a}$ & $189.58 \mathrm{c}$ & $174.17 \mathrm{c}$ \\
\hline Pionner 35 & $76.46 \mathrm{a}$ & $216.56 \mathrm{a}$ & $193.54 \mathrm{a}$ \\
\hline LSD 5\% & $\mathrm{ns}$ & 6.89 & 4.73 \\
\hline N fertilizer level & & & \\
\hline $64 \mathrm{~kg} \mathrm{ha}^{-1}$ & $76.08 \mathrm{a}$ & $202.22 \mathrm{a}$ & $178.17 \mathrm{a}$ \\
\hline $86,5 \mathrm{~kg} \mathrm{ha}^{-1}$ & $73.00 \mathrm{a}$ & $194.25 \mathrm{a}$ & $175.00 \mathrm{a}$ \\
\hline $109 \mathrm{~kg} \mathrm{ha}^{-1}$ & $75.67 \mathrm{a}$ & $197.50 \mathrm{a}$ & $179.42 \mathrm{a}$ \\
\hline $131,5 \mathrm{~kg} \mathrm{ha}^{-1}$ & $74.33 \mathrm{a}$ & $201.75 \mathrm{a}$ & $177.83 \mathrm{a}$ \\
\hline LSD 5\% & $\mathrm{ns}$ & $\mathrm{ns}$ & $\mathrm{ns}$ \\
\hline
\end{tabular}

Note: Numbers accompanied by the same letter in the same column mean that they are not significantly different according to LSD 5\%, dap (days after planting) $n s$ (not significant). 
The results of the research on the height of maize varieties of Bima 10, Bima 19, Bisi 18, Pionner 21 and Sukmaraga which between immature rubber plants there were no difference [11]. Corn planted in shade during growth and reproduction stage significantly affected corn plant height and cob height [12]. Corn varieties grown under coconut stands have the same height, include Sukmaraga, Srikandi Kuning, Lamuru, Lagaligo and Gumarang variety [13].

The data in Table 3 shows that the highest cob height in the hybrid maize varieties of Nasa 29 and Pionner 35, at $78.17 \mathrm{~cm}$ and 76.98, respectively, had a significant difference to the varieties of Bima 19, Bima 20 and JH 21. While the level of nitrogen fertilizer on corn plant height has no difference in the cob height between treatments. The statistical analysis results on the ratio of plant height to cob height show that there is no difference in the treatment of hybrid corn varieties and the level of nitrogen fertilizer treatment.

The male flowers emergence on maize were the fastest in the Pionner 35 variety, at 53 days after planting, while the Bima 20 variety had the slowest flower emergence, at 57.33 days. While the treatment of level of nitrogen fertilizer provide no difference in male flower emergence (Table 3). Further, the age of female flowers shows the same pattern as the age of male flowers, the Pionner 35 variety has female flowers that come out faster significantly different from other varieties, while the age of female flowers the longest on the Bima 20 variety. The level of nitrogen fertilizer provide no difference to the age of female flowers.

Table 3. The effect of the hybrid corn varieties treatment with level of nitrogen fertilizer on corn plants under coconut stands on observations of cob height, plant height ratio with cob height, male flower age, female flower age and delay day.

\begin{tabular}{|l|c|c|c|c|c|}
\hline \multicolumn{1}{|c|}{ Treatment } & $\begin{array}{c}\text { Cob } \\
\text { height } \\
\text { (cm) }\end{array}$ & $\begin{array}{c}\text { Ratio of } \\
\text { plant } \\
\text { height to } \\
\text { cob height }\end{array}$ & $\begin{array}{c}\text { Male } \\
\text { flower } \\
\text { age } \\
\text { (day) }\end{array}$ & $\begin{array}{c}\text { Age of } \\
\text { female } \\
\text { flower } \\
\text { (day) }\end{array}$ & $\begin{array}{c}\text { Delay } \\
\text { Day } \\
\text { (day) }\end{array}$ \\
\hline Varieties & & & & & \\
\hline Nasa 29 & $78.17 \mathrm{a}$ & $43.68 \mathrm{a}$ & $56.00 \mathrm{bc}$ & $58.67 \mathrm{c}$ & $2.67 \mathrm{a}$ \\
\hline Bima 19 & $64.90 \mathrm{~b}$ & $37.64 \mathrm{a}$ & $56.67 \mathrm{ab}$ & $59.58 \mathrm{~b}$ & $2.92 \mathrm{a}$ \\
\hline Bima 20 & $64.69 \mathrm{~b}$ & $39.13 \mathrm{a}$ & $57.33 \mathrm{a}$ & $60.58 \mathrm{a}$ & $3.25 \mathrm{a}$ \\
\hline JH 21 & $67.50 \mathrm{~b}$ & $38.99 \mathrm{a}$ & $55.33 \mathrm{c}$ & $58.75 \mathrm{bc}$ & $3.42 \mathrm{a}$ \\
\hline Pionner 35 & $76.98 \mathrm{a}$ & $39.98 \mathrm{a}$ & $53.00 \mathrm{~d}$ & $57.00 \mathrm{~d}$ & $4.00 \mathrm{a}$ \\
\hline LSD 5\% & 4.69 & $\mathrm{~ns}$ & 1.03 & 0.88 & $\mathrm{~ns}$ \\
\hline level of N fertilizer & & & & & \\
\hline $64 \mathrm{~kg} \mathrm{ha}^{-1}$ & $67.87 \mathrm{a}$ & $38.29 \mathrm{a}$ & $55.80 \mathrm{a}$ & $58.60 \mathrm{a}$ & $2.80 \mathrm{a}$ \\
\hline $86,5 \mathrm{~kg} \mathrm{ha}^{-1}$ & $68.58 \mathrm{a}$ & $39.42 \mathrm{a}$ & $55.87 \mathrm{a}$ & $59.60 \mathrm{a}$ & $3.73 \mathrm{a}$ \\
\hline $109 \mathrm{~kg} \mathrm{~h}^{-1}$ & $72.25 \mathrm{a}$ & $40.51 \mathrm{a}$ & $55.60 \mathrm{a}$ & $58.73 \mathrm{a}$ & $3.13 \mathrm{a}$ \\
\hline $131,5 \mathrm{~kg} \mathrm{ha}^{-1}$ & $73.08 \mathrm{a}$ & $41.30 \mathrm{a}$ & $55.40 \mathrm{a}$ & $58.73 \mathrm{a}$ & $3.3 \mathrm{a}$ \\
\hline LSD 5\% & $\mathrm{ns}$ & $\mathrm{ns}$ & $\mathrm{ns}$ & $\mathrm{ns}$ & $\mathrm{ns}$ \\
\hline
\end{tabular}

Note: Numbers accompanied by the same letter in the same column mean that they are not significantly different according to LSD 5\%.

The delay day data in Table 3 shows that there is no difference in the corn hybrid varieties treatment and also in the level of urea fertilizer treatment. Early-aged maize plants flowering faster than deep-aged maize [14]. Corn grown under shade will slow down the flowering age of females, male flowering age and increase the anthesis-silking interval [12]. The difference between the release of male and female flowers is in the optimal range, which is between 1.32 days [15]. Several maize varieties grown under the shade of coconuts have a male flower age of $95 \%$, which is between 60 days - 70 days [13].

The results of statistical analysis in Table 4 shows that the highest cob length on varieties Pionner 35, Nasa 29, Bima 20 and JH 21 respectively $16.91 \mathrm{~cm}, 16.66 \mathrm{~cm}, 16.42 \mathrm{~cm}$ and $15.97 \mathrm{~cm}$ significantly different to the Bima $19(15.19 \mathrm{~cm})$ variety. Nitrogen fertilization with $109 \mathrm{~kg} \mathrm{ha}^{-1} \mathrm{~N}$ and $131.5 \mathrm{~kg} \mathrm{ha}^{-1} \mathrm{~N}$ had the highest cob length of $17.20 \mathrm{~cm}$ and $17.59 \mathrm{~cm}$ 
respectively, that significantly different to the level of nitrogen fertilizer with $64 \mathrm{~kg} \mathrm{ha}^{-1} \mathrm{~N}$ and $86.5 \mathrm{~kg} \mathrm{ha}^{-1} \mathrm{~N}$. The length of corncobs planted between immature rubber plants was highest in Bisi 18 and Bima 10 varieties, at $18.39 \mathrm{~cm}$ and $18.14 \mathrm{~cm}$ respectively [11], and the range of corncob length between $15.2 \mathrm{~cm}-20.8 \mathrm{~cm}$ [13].

The statistical analysis results on the length of the cob circumference in Table 4 shows no difference in the hybrid corn varieties treatment and the level of nitrogen fertilizer treatment. The data in Table 4 shows that there is no difference in the number of seeds per cob in the hybrid corn varieties treatment. Meanwhile, the addition of nitrogen fertilizer at level of $86.5 \mathrm{~kg} \mathrm{ha}^{-1} \mathrm{~N}$ (P2) up to $131.5 \mathrm{~kg} \mathrm{~N} \mathrm{ha}^{-1}$, significantly produce more seeds per row, that ranged between 27.17 seeds to 29.17 seeds respectively compared to corn that fertilized with $64 \mathrm{~kg}$ ha- $1 \mathrm{~N}$ that produced 25.87 seeds. The results from the similar study showed no difference in the number of seeds per row in the treatments of Srikandi Kuning, Sukmaraga, Lamuru, Lagaligo, Gumarang and Manado Kuning varieties [13].

Table 4. The effect of the hybrid corn varieties treatment with level of nitrogen fertilizer on corn plant under coconut stands on the observations of cob length, cob circumference, number of seeds per row, number of seeds per circle and number of seeds per cob.

\begin{tabular}{|c|c|c|c|c|c|}
\hline Treatment & $\begin{array}{c}\text { Cob length } \\
(\mathrm{cm})\end{array}$ & $\begin{array}{c}\text { Cob } \\
\text { circumference } \\
(\mathrm{cm})\end{array}$ & $\begin{array}{c}\text { Number of } \\
\text { seeds per row } \\
(\text { seed })\end{array}$ & $\begin{array}{c}\text { Number of } \\
\text { seeds per } \\
\text { circle (seed) }\end{array}$ & $\begin{array}{c}\text { Number of } \\
\text { seeds per } \\
\text { cob (seed) }\end{array}$ \\
\hline Varieties & & & & & \\
\hline Nasa 29 & $16.66 \mathrm{a}$ & $14.42 \mathrm{a}$ & $27.08 \mathrm{a}$ & $12.08 \mathrm{a}$ & $326.92 \mathrm{a}$ \\
\hline Bima 19 & $15.19 \mathrm{~b}$ & $14.42 \mathrm{a}$ & $28.42 \mathrm{a}$ & $11.92 \mathrm{a}$ & $340.67 \mathrm{a}$ \\
\hline Bima 20 & $16.42 \mathrm{a}$ & $14.89 \mathrm{a}$ & $28.58 \mathrm{a}$ & $12.92 \mathrm{a}$ & $368.08 \mathrm{a}$ \\
\hline JH 21 & $15.97 \mathrm{ab}$ & $13.48 \mathrm{a}$ & $26.46 \mathrm{a}$ & $12.50 \mathrm{a}$ & $329.75 \mathrm{a}$ \\
\hline Pionner 35 & $16.91 \mathrm{a}$ & $14.68 \mathrm{a}$ & $27.58 \mathrm{a}$ & $13.00 \mathrm{a}$ & $343.42 \mathrm{a}$ \\
\hline LSD 5\% & 1.01 & $\mathrm{~ns}$ & $\mathrm{~ns}$ & $\mathrm{~ns}$ & $\mathrm{~ns}$ \\
\hline $\begin{array}{c}\text { Level of } \mathbf{~} \\
\text { fertilizer }\end{array}$ & & & & & \\
\hline $64 \mathrm{~kg} \mathrm{ha}^{-1}$ & $13.87 \mathrm{c}$ & $14.18 \mathrm{a}$ & $25.87 \mathrm{~b}$ & $11.67 \mathrm{bc}$ & $297.40 \mathrm{c}$ \\
\hline $86,5 \mathrm{~kg} \mathrm{ha}^{-1}$ & $16.24 \mathrm{~b}$ & $14.05 \mathrm{a}$ & $27.13 \mathrm{ab}$ & $12.33 \mathrm{ab}$ & $333.20 \mathrm{~b}$ \\
\hline $109 \mathrm{~kg} \mathrm{ha}^{-1}$ & $17.59 \mathrm{a}$ & $14.45 \mathrm{a}$ & $28.33 \mathrm{a}$ & $13.13 \mathrm{a}$ & $368.87 \mathrm{a}$ \\
\hline $131,5 \mathrm{~kg} \mathrm{~h}^{-1}$ & $17.20 \mathrm{ab}$ & $14.83 \mathrm{a}$ & $29.17 \mathrm{a}$ & $12.80 \mathrm{a}$ & $367.60 \mathrm{a}$ \\
\hline $\mathrm{LSD} \mathrm{5} \%^{1.13}$ & 1.13 & $\mathrm{~ns}$ & 2.20 & 0.86 & 30.88 \\
\hline
\end{tabular}

Note: Numbers accompanied by the same letter in the same column mean that they are not significantly different according to LSD 5\%.

The number of seeds per cob circumference in Table 4 provides consistent pattern as the number of seeds per row there is no difference in the hybrid corn varieties treatment. Meanwhile, the addition of nitrogen fertilizer at level of $86.5 \mathrm{~kg} \mathrm{ha}^{-1} \mathrm{~N}$ up to $131.5 \mathrm{~kg} \mathrm{ha}^{-1}$ of $\mathrm{N}$, result the number of seeds per cob circumference from 12.33 seeds to 13.13 seeds that significantly different to the $64 \mathrm{~kg} \mathrm{ha}^{-1} \mathrm{~N}$ application with 11.67 seeds.

The statistical analysis results of hybrid corn varieties in Table 4 have the same number of seeds per cob. Meanwhile, the addition of nitrogen fertilizer at $109 \mathrm{~kg} \mathrm{ha}^{-1} \mathrm{~N}$ and $131.5 \mathrm{~kg}$ $\mathrm{ha}^{-1} \mathrm{~N}$ had 368.87 seeds and 367.60 seeds per cob respectively, that significantly different to the result of seeds per cob on $64 \mathrm{~kg} \mathrm{ha}^{-1}$ and $86.5 \mathrm{~kg} \mathrm{ha}^{-1}$ of $\mathrm{N}$ fertilizer.

The statistical analysis results on the weight of 1000 grains in Table 5 shows the interaction between the several hybrid maize varieties treatment with the addition level of nitrogen fertilizer. The Bima 19 variety with $131.5 \mathrm{~kg} \mathrm{ha}^{-1}$ of $\mathrm{N}$ fertilizer provide the highest weight of 1000 grains with $314.33 \mathrm{~g}$. This result is not different with the Bima 20 corn variety with $109 \mathrm{~kg} \mathrm{ha}^{-1}$ and $131.5 \mathrm{~kg} \mathrm{ha}^{-1}$ of $\mathrm{N}$ fertilizer and similar to JH 21 corn variety with 86.5 $\mathrm{kg} \mathrm{ha}^{-1}$ and $131.5 \mathrm{~kg} \mathrm{ha}^{-1}$ of $\mathrm{N}$ fertilizer. These results consistent with another study of Bima 19 maize variety that planted among young rubber plants on the weight of 1000 grains of 280 
$\mathrm{g}$ [11]. Nitrogen fertilization with a dose of $112.5 \mathrm{~kg} \mathrm{ha}^{-1}$ has the same seed weight different from a nitrogen dose of $22.5 \mathrm{~kg} \mathrm{ha}^{-1}[16]$.

Table 5. Average weight of 1000 grains and maize productivity due to the interaction between hybrid maize varieties and levels of nitrogen fertilizer

\begin{tabular}{|c|c|c|}
\hline Treatment & $\begin{array}{l}1000 \text { grain weight } \\
(\mathrm{g})\end{array}$ & $\begin{array}{c}\text { Productivity } \\
\left(\mathrm{kg} \mathrm{ha}^{-1}\right)\end{array}$ \\
\hline Varieties Nasa $29+64 \mathrm{~kg} \mathrm{ha}^{-1} \mathrm{~N}$ fertilizer & $265.77 \mathrm{fgh}$ & $3,875 \mathrm{~b}$ \\
\hline Varieties Nasa $29+86,5 \mathrm{~kg} \mathrm{ha}^{-1} \mathrm{~N}$ fertilizer & $279.25 \mathrm{de}$ & $4,112 \mathrm{bcd}$ \\
\hline Varieties Nasa $29+109 \mathrm{~kg} \mathrm{ha}^{-1} \mathrm{~N}$ fertilizer & $280.53 \mathrm{cde}$ & $4,870 \mathrm{a}$ \\
\hline Varieties Nasa $29+131,5 \mathrm{~kg} \mathrm{ha}^{-1} \mathrm{~N}$ fertilizer & $278.99 \mathrm{de}$ & $4,415 \mathrm{ab}$ \\
\hline Varieties Bima $19+64 \mathrm{~kg} \mathrm{ha}^{-1} \mathrm{~N}$ fertilizer & 274.08 ef & $2,345 \mathrm{~h}$ \\
\hline Varieties Bima $19+86,5 \mathrm{~kg} \mathrm{ha}^{-1} \mathrm{~N}$ fertilizer & $281.73 \mathrm{cde}$ & $2,646 \mathrm{gh}$ \\
\hline Varieties Bima $19+109 \mathrm{~kg} \mathrm{ha}^{-1} \mathrm{~N}$ fertilizer & $287.33 \mathrm{~cd}$ & 3,674 bcde \\
\hline Varieties Bima $19+131,5 \mathrm{~kg} \mathrm{ha}^{-1} \mathrm{~N}$ fertilizer & $314.33 \mathrm{a}$ & $4,560 \mathrm{ab}$ \\
\hline Varieties Bima $20+64 \mathrm{~kg} \mathrm{ha}^{-1} \mathrm{~N}$ fertilizer & $261.58 \mathrm{fgh}$ & $2,788 \mathrm{fgh}$ \\
\hline Varieties Bima $20+86,5 \mathrm{~kg} \mathrm{ha}^{-1} \mathrm{~N}$ fertilizer & $285.02 \mathrm{cde}$ & $3,550 \mathrm{de}$ \\
\hline Varieties Bima $20+109 \mathrm{~kg} \mathrm{ha}^{-1} \mathrm{~N}$ fertilizer & $303.83 \mathrm{ab}$ & 3,161 efg \\
\hline Varieties Bima $20+131,5 \mathrm{~kg} \mathrm{ha}^{-1} \mathrm{~N}$ fertilizer & $310.58 \mathrm{a}$ & $3,895 \mathrm{bcd}$ \\
\hline Varieties JH $21+64 \mathrm{~kg} \mathrm{ha}^{-1} \mathrm{~N}$ fertilizer & $293.02 \mathrm{bc}$ & $2,651 \mathrm{gh}$ \\
\hline Varieties JH $21+86,5 \mathrm{~kg} \mathrm{ha}^{-1} \mathrm{~N}$ fertilizer & $309.06 \mathrm{a}$ & $3,470 \mathrm{def}$ \\
\hline Varieties JH $21+109 \mathrm{~kg} \mathrm{ha}^{-1} \mathrm{~N}$ fertilizer & $301.73 \mathrm{ab}$ & $3,503 \mathrm{de}$ \\
\hline Varieties JH $21+131,5 \mathrm{~kg} \mathrm{ha}^{-1} \mathrm{~N}$ fertilizer & $301.62 \mathrm{ab}$ & 3,419 def \\
\hline Varieties Pionner $35+64 \mathrm{~kg} \mathrm{ha}^{-1} \mathrm{~N}$ fertilizer & $257.62 \mathrm{gh}$ & $2,637 \mathrm{gh}$ \\
\hline Varieties Pionner $35+86,5 \mathrm{~kg} \mathrm{ha}^{-1} \mathrm{~N}$ fertilizer & $264.64 \mathrm{fgh}$ & $4,095 \mathrm{bcd}$ \\
\hline Varieties Pionner $35+109 \mathrm{~kg} \mathrm{ha}^{-1} \mathrm{~N}$ fertilizer & $263.69 \mathrm{fgh}$ & $4,275 \mathrm{abc}$ \\
\hline Varieties Pionner $35+131,5 \mathrm{~kg} \mathrm{ha}^{-1} \mathrm{~N}$ fertilizer & $255.39 \mathrm{~h}$ & 3,571 cde \\
\hline LSD 5\% & 13.23 & 706 \\
\hline
\end{tabular}

Note: Numbers accompanied by the same letter in the same column mean that they are not significantly different according to LSD 5\%.

The data in Table 5 shows the interaction between the hybrid maize varieties treatments with the level of nitrogen fertilizer. The Nasa 29 hybrid corn variety and $109 \mathrm{~kg} \mathrm{ha}^{-1}$ of nitrogen fertilizer level provide the highest productivity of $4.870 \mathrm{~kg} \mathrm{ha}^{-1}$, that significantly different to the other treatments. Several maize varieties include Bima 19, Bima 10, Bisi 18, Pionner 21 and Sukmaraga that planted among young rubber plants provide the productivity between $2.2 \mathrm{t} \mathrm{ha}^{-1}$ to $4.1 \mathrm{t} \mathrm{ha}^{-1}[13]$. The maize productivity intercrops among rubber trees is lower than the monoculture cropping by $68 \%$ [4]. The productivity of maize grown among coconuts is highest for the Srikandi Kuning and Sukmaraga varieties at $6.5 \mathrm{t} \mathrm{ha}^{-1}$ and $6.8 \mathrm{tha}^{-}$ ${ }^{1}$ respectively [13]. The productivity of free pollinated corn and hybrids is strongly influenced by the adaptability of each variety [5]. Nitrogen fertilization of $112.5 \mathrm{~kg} \mathrm{ha}^{-1}$ can increase the total wet weight of plants by $23.53 \%$ compared to the use of nitrogen fertilizers at $22.5 \mathrm{~kg}$ $\mathrm{ha}^{-1}[16]$. The linear administration level of urea for corn plant up to $300 \mathrm{~kg} \mathrm{ha}^{-1}$ can increase the yields, urea is a nitrogen source synthesis. [17]. Nitrogen is one of the important nutrients for plants, to produce protein and chlorophyll, maintain photosynthetic efficiency and increase plant dry weight [17].

\section{Conclusions}

1. Hybrid maize varieties Nasa 29, Bima 19 and Pionner 35 have a high potential to be developed on shaded land, because their productivity is higher than other varieties. 
2. Hybrid corn planted under the shade of coconut with a dose of Nitrogen fertilizer $109 \mathrm{~kg}$ $\mathrm{ha}^{-1}$ and $\mathrm{N}$ : $131.5 \mathrm{~kg} \mathrm{ha}^{-1}$ can increase productivity yields $26-28 \%$.

\section{References}

1. Badan Pusat Stastistik Kalimantan Barat. 2018. Kalimantan Barat Dalam Angka. Badan Pusat Stastistik Kalimantan Barat, (2018)

2. J. Barus, Jurnal Lahan Suboptimal, 2, 1 (2013)

3. Badan Pusat Statistik Provinsi Kalimantan Barat, 2021. Kalimantan Barat Dalam Angka Tahun 2021. Badan Pusat Statistik Provinsi Kalimantan Barat. Pontianak, (2021)

4. Sahuri, Jurnal Analisis Kebijakan Pertanian, 15, 2 (2017)

5. Sutoro, Jurnal IPTEK Tanaman Pangan, 10, 1 (2015)

6. D. Saragih, H. Hamim, N. Nurmauli, Jurnal Agrotek Tropika, 1, 1 (2013)

7. Muyassir, J. Manajemen Sumberdaya Lahan, 2, 3 (2013)

8. J. Zhang, H.L. Zhao, K.L. Wei-Huang, H.S. Lian, Journal of Water Resource and Protection, 12, 4 (2012)

9. G.A. Shaila, A. Tauhid, I. Tustiyani, Jurnal Agritrop., 17, 1 (2019)

10. Gomez, A. Kwanchai, A.A. Gomez, Statistical Procedures for Agricultural Research. Second Edition. An International Rice Research Institute Book. (A Wiley Interscience Publication, 1984)

11. Y. Suparwoto, Y. Juwita, Y. Hutapea, Jurnal Sosial Ekonomi Pertanian, 13, 2 (2019)

12. L.J. Yuan, X. Tang, Wang, C. Li, PLoS ONE, 7, 6 (2012)

13. Y. Tamburian, Buletin Palma, 13, 1 (2012)

14. L.L. Garba, O.A.T. Namo, African Crop Science Journal. 21 (2013)

15. S. Subaedah, S. Numba, Saida, J. Agron. Indonesia, 46, 2 (2018)

16. A.T. Buana, D.E. Munandar, H.B. Setyawan, Jurnal Berkala Ilmiah Pertanian, 1, 1 (2014)

17. A.I. Masruroh, H. Hamim, N. Nurmauli, J. Agrotek Tropika, 5, 1 (2017) 